\title{
Contrastive analysis of Turkish and English in Turkish EFL learners' spoken discourse
}

\author{
MustaFA YILDIZ* \\ Anadolu University
}

Received: 18/11/2014. Accepted: 11/07/2015.

\begin{abstract}
The present study aimed at finding whether L1 Turkish caused interference errors on Turkish EFL learners' spoken English discourse. Whether English proficiency level had any effect on the number of errors learners made was further investigated. The participants were given the chance to choose one of the two alternative topics to speak about. The entire videotaped speaking session was further transcribed to analyze the spoken errors. The results indicated that prepositional, lexical, and grammatical errors were the most frequently encountered errors, in descending order. Also, independent samples t-test was applied to the data to determine whether English proficiency level had any effect on the number of errors made by two different English proficiency groups. It was found that there was no significant difference between two different English proficiency groups with regard to the number of errors they made.
\end{abstract}

KEYWORDS: L1 interference, error analysis, interlingual errors, contrastive analysis, L1 based errors.

\section{INTRODUCTION}

Making an error is a natural occurrence about which several views have been proposed to account for why it comes true. While Patten and Benati (2010: 68) underline that behaviourism regards the learners' errors as a shortcoming which should be compensated immediately, Kırkgöz (2010: 4352) shows in her study that according to the cognitive view learner errors should be viewed as a sign of progress in learners' interlanguage system. Even Kroll and Schafer (1978: 242-243) assert that "[e]rror-analysts are cognitivists, not behaviourists, in their psychological orientation". Despite the fact that different standpoints

\footnotetext{
*Address for correspondence: Mustafa Yildiz. Sema-Cengiz Büberci Mesleki ve Teknik Anadolu Lisesi. İstiklal Caddesi, No: 143, İlkadım/SAMSUN, Turkey; e-mail: myildiz55@yahoo.com.
} 
are available about how to react to learners' errors, the existence of errors is the only aspect on which different views reach a consensus. While Corder (1967: 163) emphasizes that behaviourists believe that the success of the teaching methods and the chances of making an error are inversely proportional, cognitivists assert that perfection in teaching does not change the inevitability of errors. Gass and Selinker (2008: 102) and Saville-Troike (2006: 38) refer to Corder's study (1967), who deals with errors from a different point of view highlighting their importance in terms of what they reveal as to the actual progress of language learners. At this point, Corder's study is a starting point for the error analysis which focuses on learners' performance errors rather than on competence ones in the target language.

Error Analysis as a cognitive approach appears as a reaction to behaviorist Contrastive Analysis Hypothesis. While Contrastive Analysis compares and contrasts the similarities and differences between the mother tongue and the target language to detect prospective difficulties language learners may encounter, Error Analysis scrutinizes the learners' errors to shed light on the learners' in-process interlanguage system. According to Corder (1967: 167), learners' errors do not only inform the teacher about the learners' actual development, but also give learners the chance to test several hypotheses related to their language learning, and supply researchers with language learning strategies and procedures utilized by language learners.

\section{STATEMENT OF THE PROBLEM}

Errors are indispensable elements of not only first language acquisition but also of second language learning process. It should be added that not only are errors meaningful, but also the underlying reasons for them. It is just like a teacher's recommendation to his/her students about revising the wrongly-answered questions at the end of the test. In other words, as Saville-Troike (2006: 38-39) proposes, “errors are windows into the language learner's mind"; however, they only show evidence of a learner's interlanguage in progress if they are analyzed to unearth the underlying reasons why the learner makes errors. The solution is to analyze the learner's errors to provide insights into how the learners' interim grammar takes form.

Jarvis and Pavlenko (2008) classify a large variety of cross-linguistic influences under the term 'linguistic transfer', which includes various subtypes: phonological, orthographic, lexical, semantic, morphological, syntactic, discursive, pragmatic, and socio-linguistic. The present study is directly associated with linguistic transfer by investigating lexical, grammatical and prepositional errors originated from L1 interference.

Error analysis has been subjected to increasingly critical scrutiny for a long time. A wide range of studies (e.g. Abbasi \& Karimnia, 2011; Alonso-Alonso, 1997; Butt \& Rasool, 
2012; Gustilo \& Magno, 2012; Khansir, 2013; Londoño-Vásquez, 2008; Nezami \& Najafi, 2012; Watcharapunyawong \& Usaha, 2013; Zheng \& Park, 2013) has focused on the learners' error analysis on written learner products. However, very little research (e.g. Dulay \& Burt, 1974; Politzer \& Ramirez, 1973; Ting, Mahadhir \& Chang, 2010) has delved into learners' spoken error analysis. Ting, Mahadhir and Chang (2010: 54) refer to this scarcity of literature on error analysis of oral interlanguage as "near-absence of attention". While two of the three studies related to spoken error analysis (i.e. Dulay \& Burt, 1974; Politzer \& Ramirez, 1973) focus on participants learning English as their second language, the other (i.e. Ting, Mahadhir \& Chang, 2010) shows similarities with the present study in that its participants learn English as their foreign language. Whereas almost all the studies mentioned above, especially those on written learner products, include university students as their participants, the present study differs from all related studies in that the participants are from a private high school.

Our study is designed to analyze English language learners' errors in their L2 speech in an attempt to deduce strategies L2 learners have tested during their language learning process. Thus, the main issue addressed is whether the learners' L1 grammatical competence interferes with L2 canonical structures and consequently gives rise to errors while they are speaking in the target language. That is to say, the study is carried out to determine grammatical, lexical and prepositional errors originating from learners' mother tongue and produced during speaking courses, and to inquire about learners' interlanguage development. This study is of potential interest for various types of audiences, especially for English language teachers, who can better understand their students' needs and difficulties, and be informed about the learners' actual progress in language learning process. In the present case, the learners' analyzed errors can be taken as feedback for teachers to deduce, if relevant, the potential obstacles arising from the mother tongue. On the other hand, precautions taken by teachers let the learners realize they have made errors and thus have the opportunity to diminish them.

\section{THEORETICAL FRAMEWORK}

\subsection{Description of error}

Errors, observed in L2 English production, are natural outcomes of the language learning process. While Londoño-Vásquez (2008: 136) describes errors as deviant language structures with regard to the standards of the target language, Şanal (2008: 599) underlines that errors are systematic deviations from the target language because of learners' lack of underlying knowledge. According to Brown (2007: 258), errors mirror the second language learners' competence level: an error does not only point to mislearning but also to actual underlying 
knowledge of second language learners. Corder (1967: 165) states that errors both prove that the language acquisition process is active and indicate the actual knowledge of learners in the acquisition process. Rather than labelling learner errors as avoidable elements, trying to benefit from them to a certain extent is beneficial for learners and teachers reciprocally. Learner errors, in some ways, take the form of feedback for teachers in terms of assessing learners' actual progress, and also provide learners with potential corrective feedback from their teachers.

\subsection{Types and sources of errors}

Having clarified what the error and its place in second language acquisition are, it is important to explore the potential sources of errors according to the relevant literature. Corder (1973, in Erdoğan, 2005: 264) groups the sources of errors into four categories: 'omission', 'addition', 'selection', and 'misordering'. Thus, omitting required components, adding nonessential elements, selecting incorrect constituents, and misordering syllables, words, or morphological items are described as sources of errors. Ellis (2003: 19) summarizes the potential sources of error as 'omission', 'overgeneralization', and 'transfer'. In addition to Corder's classification, overgeneralization of relatively easy forms to other inapplicable situations and learners' effort to use their L1 data in the course of L2 production are identified as error-causing reasons.

Gass and Selinker (2008: 103) focus on two different kinds of error types; i.e. 'interlingual' and 'intralingual' errors. Whereas interlingual errors stem from learners' native language, intralingual errors are motivated by the target language itself. Brown (2007: 263) asserts that the starting period of second language learning is more likely to be influenced by the negative effect of learners' native language (the only available language system), on which learners are able to build the new language system. Brown (2007: 264) also identifies overgeneralization (a kind of error source) as negative intralingual transfer, since it appears when misusing target language rules for any other target language structure, thus causing errors that arise from the target language itself. In other respects, Burt (1975: 56-57) divides the errors into two parts, as 'global' and 'local' errors. While errors corrupting general structure of the sentence and blocking the healthy communication between interlocutors are referred to as global errors, the ones influencing only limited part of a sentence and having no effect on intended meaning are termed local errors.

\subsection{Error analysis and its importance}

Brown (2007: 381) accounts for error analysis as "the study of learners' ill-formed production (spoken or written) in an effort to discover systematicity". It is a kind of elaborative inquiry of learners' errors to determine how learners' interlanguage system 
evolves. Ellis (2003: 15) underlines that even though analysing learners' errors instead of their accurate use of language seems to be somehow atypical, there are rational reasons why researchers concentrate upon learners' deviant use of target language structures. According to Kroll and Schafer (1978: 243), "errors help the teacher identify the cognitive strategies that the learner is using to process information". Corder (1967: 167) considers errors a prerequisite for the learning process, since learners use errors as an aid to test hypotheses and to learn. He also emphasizes the elucidative feature of analyzed errors, notifying teachers about existing learner knowledge (1967: 167). Finally, Gass and Selinker (2008: 103) state that errors are viewed as "indications of a learner's attempt to figure out some system to impose regularity on the language the learner is exposed to".

\subsection{Past research related to error types in written data}

Londoño-Vásquez (2008) analyzes a composition written by a Spanish-speaking EFL learner to evaluate errors. Four different types (omission, additions, misinformation, and misordering) are identified as causes of the learner's errors. Additionally, the composition contains interlanguage errors because of the different structures used in Spanish and English. In turn, Bhela (1999) investigates L1-based syntactic errors in written compositions of four different non-native English speakers. After determining the learners' L1 and L2 writing proficiency and finding similar achievement level across participants, two different compositions, in English and in their native languages, are expected to be written after two sets of pictures are shown. The compositions written in English are interpreted by three native speakers of English with regard to their semantic and syntactic acceptability. The results conclude that, even though the compositions contain L1-based interference errors, they are understandable by native speaker raters and do not have to be syntactically impeccable to be understood.

Elkılıç (2012) searches 1078 written papers of intermediate and upper-intermediate level Turkish university students for detecting the interference errors made by the learners. The L1-based errors are classified into misuse of prepositions and uncountable nouns, confusion of certain verbs, omission of the indefinite article, use of demonstrative adjectives, and word-for-word translation from learners' mother tongue. The results also underline that the level of English knowledge and the frequency of errors are inversely proportional. A similar study is conducted by Nezami and Najafi (2012) with 103 Iranian EFL learners with three different English proficiency levels. At the outset of the study, the researchers define the proficiency level of learners and instruct the participants to write a composition. The analysis of the written learner products shows that the five most frequently encountered error types are punctuation, wrong lexical/phrase choice, faulty spelling, and incorrect use of articles and verb formation. The study also shows that learners with different English proficiency levels differ significantly in terms of the frequency of their errors. 
As for elementary level learner lexical errors, Ander and Y1ldırım (2010) collect written data from 53 EFL learners to evaluate and classify this type of errors. Their results yield seven different types: wrong word order choice, literal translation, omission or incompletion, misspelling, redundancy, problems with collocation, and wrong word formation. Of these, errors of the first type in the list, which make the sentence meaningless, are the most frequent ones. The second most frequent errors are misspelling and omission. While the former does not have any effect on the meaning of the sentence, the latter causes a partial or a complete meaning corruption. Khansir (2013) conducts a similar study in which the written errors committed by 200 undergraduate level Iranian and Indian adult students are grouped into five categories, compared and analyzed. He reaches the conclusion that spelling is the least frequent type of error made not only by Iranian but also by Indian learners, contrary to the results of Ander and Yildırım (2010) with regard to the frequency of learner errors. Whereas punctuation is the most common error type among Iranian learners, incorrect use of articles is the most frequent type of error of Indian learners. However, it can easily be observed that the most frequent error type for each group turns into subsidiary when the following most common errors are regarded. The other two error types are incorrect use of connectors and conjunctions.

In another study, which analyzes 17 written compositions to determine the lexical, grammatical, and syntactic errors made by adult EFL learners, Erkaya (2012) groups the learners' errors into global and local, as Burt (1975) suggests. As with Ander and Y1ldirım's study (2010), both lexical errors (viewed as a complicating factor that causes readers not to comprehend the intended meaning) and incorrect word choice are regarded as global errors. Incorrect use of word choice, articles, prepositions, punctuation, and singular/plural noun agreement are the most frequently encountered types of errors. Incorrect use of articles, prepositions, punctuation, and singular-plural noun agreement are described as L1-based interference appearing in the production of L2 English learners.

Kırkgöz (2010) examines 120 compositions written by beginner-level Turkish adult EFL learners to reveal potential reasons of errors. With the result that the frequency of interlingual errors outnumbers that of intralingual errors, Kırkgöz concludes that beginnerlevel learners are more likely to experience the negative effect of transfer from their native languages while producing the target language forms. While interlingual errors are subcategorized as grammatical, prepositional, and lexical interference, intralingual errors are divided into overgeneralization, incorrect use of articles, spelling, and redundancy. This evinces different classifications of errors, since, for example, the incorrect use of articles is placed under different error types by different researchers. Whereas Erkaya (2012) classifies incorrect use of articles as an interlingual error, Kırkgöz (2010) categorizes it as intralingual. Nonetheless, and regardless of its categorization, the incorrect use of articles is one of the most frequent errors. 
Gustilo and Magno (2012) analyze 150 essays written by college students with three different English proficiency levels (low, mid, and high). The results indicate that the most frequent errors by the three groups are related to incorrect use of the comma, word order choice, verbs, capitalization, punctuation and sentence structure, and that the groups do not differ significantly with regard to their mean scores on the error categories mentioned.

\subsection{Past research related to error types in spoken data}

The study by Politzer and Ramirez (1973) aims at categorizing the spoken English errors of Mexican-American pupils and at investigating whether the total number of learner errors differs with regard to type of schooling. Errors are classified into morphological, syntactic and vocabulary. The results indicate that there is no significant correlation between type of schooling (monolingual or bilingual school) and the total number of spoken errors.

Dulay and Burt (1974) scrutinize 513 syntactic errors occurred in the speech of 179 Spanish-speaking children aged 5 to 8 to bring to light whether syntactic errors are due to L1based reasons or to developmental processes used as in L1 acquisition. At the end of the study, the errors are grouped into three categories: developmental errors, which resemble those appearing during the L1 acquisition; interference errors, occurring just because of the L1 and L2 syntactic differences; and unique errors, which do not resemble any of the other two types. The results demonstrate that while $4.7 \%$ of errors originate from L1 Spanish interference, $87.1 \%$ of errors derive from developmental structures identical to the ones children experience while learning their mother tongue. The remaining $8.2 \%$ are unique errors, which do not result from L1 Spanish interference or are not parallel to errors committed while learning English as a first language.

Ting, Mahadhir and Chang (2010) investigate the types of grammatical errors in the speech of university students and examine whether the learners' grammatical accuracy improves throughout the process. The results indicate that preposition errors and question form errors are the most frequent grammatical errors. Further results show that the learners seem to improve their grammatical accuracy by the end of the research process.

To sum up, even though all the above-mentioned studies are related to errors and contrastive analysis in general, they show clear differences. First, while most of them deal with the issue with regard to written products, few studies analyze spoken discourse. Second, even though some studies classify the errors into two groups (interlingual and intralingual errors), others concentrate on only L1-based interferences to analyze the issue in depth. Finally, some studies focus on the analysis of the errors made by different English proficiency groups. In this respect, whereas in some studies the groups statistically differ from each other in terms of the frequency of errors, in others the proficiency level has no significant effect on the frequency of learners' errors. 
This literature review leads us to consider the following research questions:

1. What are the instances, stemming from the L1 structure, causing error in L2 speech production?

2. Does the proficiency level of learners have any significant effect on the frequency of L1 interference errors?

\section{METHODOLOGY}

\subsection{Participants}

The participants of the present study, amounting to 30 students (20 of whom are upperintermediate level and 10 of whom are intermediate level EFL learners), are selected by one non-probability sampling technique, convenience sampling technique. All of them study at S.E.S. private high school in Samsun (Turkey) and are subjected to take Oxford Placement Test to determine their English proficiency level slightly after they have enrolled in the school at the outset of the academic year. The school has students from three different grades, i.e. $9^{\text {th }}, 10^{\text {th }}$, and $11^{\text {th }}$. The English courses are designed not according to the grades but to the proficiency level of learners. In other words, not all students attending $9^{\text {th }}$ grade, for example, take the same English course, due to their different English proficiency level. The same applies to the students in the other two grades.

\subsection{Procedure}

In order to investigate potential effect of L1 on learners' L2 English spoken interlanguage, the participants are expected to talk about one of the two optional topics: a) their expectations about the future, their plans and their effort to make them real; and $b$ ) the problems they frequently confront in their daily life and the solution they offer. The students are allowed to think a few minutes about the topic they would like to talk about. The entire speaking session is videotaped for the purposes of transcribing their performances and of analysing the spoken errors. A video camera, instead of just an audio recorder, is used to exactly discriminate the voices of speakers in the situations in which there is more than one speaker. Before collecting the data, the participants are informed about the research problem and the purpose of the study. Participants are also informed that their performance does not affect their grade.

\subsection{Data analysis}

In order to respond to the first research question, the videotaped data were first transcribed and then the participants' errors emanated from L1 Turkish were grouped under three 
headings: grammatical, prepositional, and lexical interferences. Intelligent verbatim transcription technique, in which recordings related to non-verbal communication and filler words were avoided, was used. The researcher preferred intelligent verbatim technique to true verbatim technique because detailed style in true verbatim did not contribute to the aim of the study. The present study, by virtue of its aim, gave more importance to what was uttered by the participants rather than to how they did so. An excerpt from the transcribed text was as follows:

[...] in the future... I want to be a student at Koç University. After graduate in this university, I want to gain my biggest expectation...I want to be an architect. I have a lot of responsibilities... in order to make it real... I know... So I work very hard... day and night. But one of my problem is... I have problem... with my homework... We have a lot of homework to do... and... sometimes I don't want to do homework... I think... It is my major daily problem...

Even though prepositional errors were grammatical errors, they were inspected under a separate subheading because of their abundance. Dulay, Burt and Krashen's surface strategy taxonomy (1982: 150), including omission, addition, misformation, and misordering as ways of deviation from standard English, was applied to classify grammatical and prepositional interferences. Lexical interferences were grouped under two subheadings, i.e. wrong word preference and word-for-word translation. The data were inspected with the help of an instructor with a Ph.D degree in ELT. Since these participants' speaking performances were not graded and the number of errors each participant made was determined together, interrater reliability was not computed. In order to distinguish errors from mistakes, deviations from standard English of the same type occurring more than once were accepted as errors. For example, the omission of the indefinite article ' $a$ ' more than once by a speaker was accepted as an error.

In order to see the effects of English proficiency level on the total number of errors made by participants, an independent samples t-test was further conducted.

\section{RESULTS}

As seen in Table 1 below, misuse of noun pluralization, of quantifier and noun agreement, and of indefinite articles appear as subheadings under grammatical interference; and omission, addition, and misformation of prepositions are the subheadings under prepositional interference. Wrong word preference and word-for-word translation are the subheadings under lexical interference: 


\begin{tabular}{|l|l|l|}
\hline & \multicolumn{1}{|c|}{ DEFINITION } & EXAMPLE \\
\hline Grammatical Interference & $\begin{array}{l}\text { Misformation in mass noun } \\
\text { pluralization }\end{array}$ & *Homeworks are... \\
\hline Noun Pluralization & $\begin{array}{l}\text { Omission of plural } \\
\text { morphological marker }\end{array}$ & $*$ a lot of question \\
\hline Quantifier and Noun Agreement & $\begin{array}{l}\text { Omission and addition of } \\
\text { morphological indefinite } \\
\text { article }\end{array}$ & *to be actress \\
\hline Misuse of Indefinite Articles & $\begin{array}{l}\text { Addition of an unnecessary } \\
\text { preposition }\end{array}$ & *marry with a person \\
\hline Prepositional Interference & $\begin{array}{l}\text { Use of an incorrect preposition } \\
\text { instead of the correct one }\end{array}$ & *in weekends \\
\hline Addition & \multicolumn{2}{|l}{} \\
\hline Misformation & Unnatural word selection & $*$ informal clothes \\
\hline Lexical Interference & $\begin{array}{l}\text { Direct translation from } \\
\text { Turkish into English }\end{array}$ & *be a child doctor \\
\hline Wrong Word Preference & Word-for-word Translation
\end{tabular}

Table 1. Definition and examples of subcategorized interlingual errors ${ }^{1}$

\subsection{Grammatical interferences stemming from L1 Turkish structure}

Turkish and English, members of two different language families, have naturally several different grammatical structures. Transferring grammatical rules from Turkish to English causes Turkish EFL learners to make errors while writing or speaking English. The absence of an English grammatical structure in Turkish also causes errors in learner products.

As shown in Table 2 below, three different types of grammatical errors are found in the analysis of the participants' speech:

\begin{tabular}{|c|c|c|}
\hline UTTERED FORM & TYPE & EXPECTED FORM \\
\hline$\ldots$ a lot of expectation... & Quantifier and noun agreement & ... a lot of expectations... \\
\hline$\ldots$ a lot of question... & Quantifier and noun agreement & $\ldots$ a lot of questions... \\
\hline ...to be actress... & $\begin{array}{l}\text { Misuse (omission) of indefinite } \\
\text { articles }\end{array}$ & $\ldots$ to be an actress... \\
\hline $\begin{array}{l}\ldots \text { wants them to be like } \\
\text { robot... }\end{array}$ & $\begin{array}{l}\text { Misuse (omission) of indefinite } \\
\text { articles }\end{array}$ & ... wants them to be like a robot \\
\hline $\begin{array}{l}\ldots \text { work abroad, for the } \\
\text { example; European countries }\end{array}$ & $\begin{array}{l}\text { Misuse (addition) of indefinite } \\
\text { article }\end{array}$ & $\begin{array}{l}\text {... work abroad, for example; } \\
\text { European countries }\end{array}$ \\
\hline My the solution offer... & $\begin{array}{l}\text { Misuse (addition) of indefinite } \\
\text { articles }\end{array}$ & My solution offer... \\
\hline $\begin{array}{l}\text { Personality are most important } \\
\text { thing... }\end{array}$ & $\begin{array}{l}\text { Misuse (omission) of indefinite } \\
\text { article }\end{array}$ & $\begin{array}{l}\text { Personality is the most } \\
\text { important thing... }\end{array}$ \\
\hline$\ldots$ but second thing... & $\begin{array}{l}\text { Misuse (omission) of indefinite } \\
\text { article }\end{array}$ & $\ldots$ but the second thing... \\
\hline Homeworks are... & $\begin{array}{l}\text { Noun pluralization } \\
\text { (misformation) }\end{array}$ & Homework is... \\
\hline
\end{tabular}

Table 2. Grammatical interference items 
As shown in Table 2, the quantifiers referring to plurality in English require plural nouns to follow them. However, the case is completely different in Turkish, where it is not a rule that plural nouns have to follow quantifiers referring to plurality. In addition to the grammatical difference between Turkish and English, absence of indefinite articles in Turkish is another factor causing errors in Turkish EFL learners' discourse in English. Not only omission, but also addition of indefinite articles, easily leap to the eye. Pluralization of uncountable nouns is another case absent in Turkish. Thus, it is another factor raising difficulties and causing errors while speaking English.

\subsection{Prepositional interference stemming from $L 1$ Turkish structure}

Prepositions do not appear in Turkish as a separate grammatical structure. They are used as postpositions adjacent to the noun to express accusative, dative, and genitive cases. However, the situation is completely different in English, in which prepositions are separate items that are used independently.

Table 3 shows the misuse of prepositions by Turkish EFL learners:

\begin{tabular}{|l|l|l|}
\hline \multicolumn{1}{|c|}{ UTTERED FORM } & \multicolumn{1}{c|}{ TYPE } & \multicolumn{1}{c|}{ EXPECTED FORM } \\
\hline$\ldots$ go to abroad...(x2) & Addition of preposition & $\ldots$ go abroad... \\
\hline$\ldots$ study about engineering... & Addition of preposition & $\ldots$ study engineering ... \\
\hline $\begin{array}{l}\ldots \text { marry with a } \\
\text { stranger/person/girl... (X3) }\end{array}$ & Addition of preposition & $\begin{array}{l}\ldots \text { marry a } \\
\text { stranger/person } / \text { girl... }\end{array}$ \\
\hline$\ldots$ for make real... & Misformation of preposition & $\ldots$ to make real... \\
\hline$\ldots$ talk on justice in Turkey... & Misformation of preposition & $\begin{array}{l}\ldots \text { talk about justice in } \\
\text { Turkey... }\end{array}$ \\
\hline$\ldots$ in weekends... & Misformation of preposition & $\ldots$ at weekends \\
\hline$\ldots$ go out from school... & Misformation of preposition & $\ldots$ go out of school... \\
\hline$\ldots$ agree about... & Misformation of preposition & $\ldots$ agree on... \\
\hline$\ldots$ problem about justice... & Misformation of preposition & $\ldots$ problem with justice... \\
homewow our time with doing & Misformation of preposition & $\begin{array}{l}\ldots \text { spend our time on doing } \\
\text { homework... }\end{array}$ \\
\hline$\ldots$ shout to students... & Misformation of preposition & $\ldots$ shout at students... \\
\hline
\end{tabular}

Table 3. Prepositional interference items

As seen in Table 3, Turkish learners make errors by adding an extra preposition or by replacing the preposition required with an incorrect one. The number of misformation errors outnumbers the number of addition errors. It is easily seen that these additions and replacements arise from thinking in Turkish, which is related to trying to say something in their mother tongue by translating into English. 


\subsection{Lexical interference stemming from $L 1$ Turkish structure}

These types of errors are derived from the learners' selection of wrong lexical items and from direct translation from Turkish into English instead of using exact word or word groups:

\begin{tabular}{|c|c|c|}
\hline UTTERED FORM & TYPE & EXPECTED FORM \\
\hline$\ldots$ be a child doctor & Word-for-word translation & ... be a pediatrician-pediatrist \\
\hline $\begin{array}{l}\ldots \text { after graduate in this } \\
\text { university... }\end{array}$ & Word-for-word translation & $\begin{array}{l}\ldots \text { after graduating from this } \\
\text { university... }\end{array}$ \\
\hline ... start to study at the now... & Word-for-word translation & ... start to study now... \\
\hline $\begin{array}{l}\ldots \text { gain my biggest } \\
\text { expectation... }\end{array}$ & Word-for-word translation & $\begin{array}{l}\text {... make my biggest expectation } \\
\text { real... }\end{array}$ \\
\hline $\begin{array}{l}\ldots \text { give my children to public } \\
\text { school... }\end{array}$ & Word-for-word translation & $\begin{array}{l}\text {... enrol my children in public } \\
\text { school... }\end{array}$ \\
\hline$\ldots$ informal clothes... & Wrong word preference & ... casual clothes... \\
\hline$\ldots$ turn them real... & Wrong word preference & ... make them real... \\
\hline ... go to abroad (for master). & Wrong word preference & $\begin{array}{l}\text {.. go abroad for Master's study } \\
\text { (degree). }\end{array}$ \\
\hline$\ldots$ gain my doctorate... & Wrong word preference & ... get/complete my doctorate... \\
\hline$\ldots$ open my own business... & Wrong word preference & $\ldots$ start my own business... \\
\hline ... do many clothes... & Wrong word preference & ... make many clothes... \\
\hline ... trying to be concentrate... & Wrong word preference & ... trying to be concentrated... \\
\hline ... major daily problem... & Wrong word preference & ... main daily problem... \\
\hline
\end{tabular}

Table 4. Lexical interference items

As shown in Table 4, direct translation from Turkish into English and use of inappropriate lexical items instead of the correct ones cause L1 interference in learners' speaking performance. The lexical interference results indicate that the learners not only transfer Turkish meaning into English directly but also match an irrelevant target word with an irrelevant word group, as they cannot recall the standard use of English in the course of speaking.

\subsection{Overall frequency of errors and its relevance to the English proficiency}

Having classified interference errors made by the participants into groups and counted, the total number of errors found amounts to 36 .

Table 5 summarizes the errors, classified according to each error type, made by each group: 


\begin{tabular}{|l|r|r|}
\hline \multicolumn{1}{|c|}{ ERROR TYPES } & \multicolumn{1}{|c|}{ INTERMEDIATE } & UPPER-INTERMEDIATE \\
\hline Grammatical interference & $\mathbf{4}$ & $\mathbf{5}$ \\
\hline Noun Pluralization & - & 1 \\
\hline Quantifier and noun agreement & 1 & 1 \\
\hline Misuse of indefinite articles & 3 & 3 \\
\hline Prepositional interference & $\mathbf{7}$ & $\mathbf{7}$ \\
\hline Omission & - & - \\
\hline Addition & 6 & - \\
\hline Misinformation & 1 & 7 \\
\hline Lexical interference & $\mathbf{5}$ & $\mathbf{8}$ \\
\hline Wrong word preference & 2 & 6 \\
\hline Word-for-word translation & 3 & 2 \\
\hline TOTAL & $\mathbf{1 6}$ & $\mathbf{2 0}$ \\
\hline
\end{tabular}

Table 5. Distribution of interlingual errors with regard to English proficiency levels

The error type that the learners most frequently make is prepositional interference. It is easily noticed that while learners with intermediate proficiency level of English misuse prepositions by adding an extra item, learners with upper-intermediate proficiency level of English replace the preposition required with an incorrect one. The error type that ranks second is lexical interference. While the number of errors made by the two different English proficiency groups is close to each other regarding word-for-word translation, wrong word preference errors made by upper-intermediate learners outnumber those made by the intermediate level group. The least frequent error type in both groups is grammatical interference. The number of errors labelled misuse of indefinite articles and quantifier and noun agreement is equal for both groups, while learners with intermediate level English proficiency do not make any noun pluralization error.

In order to answer the second research question, independent samples t-test are applied to determine whether proficiency level has any effect on the number of errors learners make or not:

\begin{tabular}{|l|l|r|r|r|r|}
\hline & PROFICIENCY & \multicolumn{1}{|c|}{ N } & MEAN & STD. DEVIATION & STD. ERROR MEAN \\
\hline $\begin{array}{l}\text { Number } \\
\text { of errors }\end{array}$ & Intermediate & 10 & 1,60 &, 966 &, 306 \\
\cline { 2 - 6 } & Upper-intermediate & 20 & 1,00 & 1,338 &, 299 \\
\hline
\end{tabular}

Table 6. Group statistics

The findings indicate that there is not any statistically significant difference between intermediate $(M=1,60 ; S D=, 966)$ and upper-intermediate $(M=1,00 ; S D=1,338)$ groups in terms of the number of errors made by the total of learners $(t(28)=1,259, p=, 218)$. It can be concluded that proficiency level is found not to have any significant effect on the number of errors made by the learners in the present study $(\mathrm{p}>, 05)$. 


\section{DISCUSSION}

The present study shows that prepositional interference errors are the most frequently encountered error types in Turkish EFL learners' speaking performances. Lexical and grammatical interference errors are the following error types.

When the results of the present study are compared with recent studies, especially those related to whether Turkish has any interference with English, differences emerge. First, misuse of prepositions is one of the least frequent error types according to Elkılıç (2012: 662) and contrary to the findings of the present study. Similarly, while word-for-word translation is the most frequent interference error in Elk1lıç (2012), this type is one of the least frequent interference errors in the present study. Even though the participants in Elkıliç (2012) have the same English proficiency level as those participating in the present study, the reason for the difference between these two studies may be found in his methodology, in which written learner products are analyzed. In another study, in which Turkish EFL learners' written compositions are searched for to reveal the L1 interference errors, Erkaya (2012) reaches the conclusion that lexical (wrong word preference), grammatical (misuse of indefinite articles), and prepositional interference are the three most frequent error types in descending frequency. In turn, Kırkgöz's 2010 study on written interference errors made by Turkish EFL learners reveals that grammatical interference is the most frequent error, followed by prepositional and then lexical interference errors. All of these results show that the written interference errors made by Turkish EFL learners are inconsistent with regard to their ordering in each of these studies. Thus, the results of our study can also indicate that each of the two productive skills causes different interference error types and with different frequencies.

At this point, collecting only spoken data seems one of the limitations of the present study. Future researchers should investigate both written and spoken data in the same study to find out the correlation between spoken and written errors and explore whether the results obtained are consistent with each other. Knowing whether the same participant makes different errors or not while speaking and writing may give an idea about how learners internalize target language structures.

Whether the number of errors differs significantly with regard to the learners' English proficiency level is another issue of concern in the present study. The past related studies (Elkılıç, 2012; Gustilo \& Magno, 2012; Nezami \& Najafi, 2012) focus on the effects of English proficiency levels on the number of errors learners made. When the English proficiency level increases, the number of errors learners make decreases in all of the abovementioned related studies. It can then be concluded that there is a negative correlation between English proficiency level and the number of errors. However, whether the rate of this correlation is meaningful (in other words, whether it can be extended to the population), is not directly proportional to the negative correlation (i.e. the case in which the higher the 
English proficiency level of the learners, the fewer the errors made by the learners, or vice versa). As Gustilo and Magno (2012) show, even though the mean of the number of errors made by three different groups with different English proficiency levels decreases with higher proficiency, this mean difference is not meaningful and cannot be generalized to the population. As also found in Elkılıç (2012), although the number of errors decreases while the proficiency level gets higher, the analysis of whether this difference is statistically significant or not is not reported between results. In the present study, and contrary to the expectations of the researcher, the distribution of the number of errors made by the learners runs counter to the above-mentioned studies. Although the mean of the number of errors made by the learners with upper-intermediate English proficiency level is lower than that of the learners with intermediate English proficiency level, higher English proficiency level brings about both increasing number of errors made by upper-intermediate level learners and non-significant statistical results. The presence of non-homogeneous groups with regard to the number of participants is the main reason for this and may be viewed as another limitation of the present study. Further studies should be conducted with different English proficiency groups in which the number of participants has been distributed homogeneously. More crowded groups may generate many more errors compared with the limited number of those in the present study, which will allow for more satisfactory results.

Forming a corpus as in Ting, Mahadhir and Chang (2010), in which not only the number of errors but also the number of words uttered by learners are counted, could be helpful for future researchers to determine the ratio of a learner's errors and the total number of words uttered throughout data collection process. In doing so, it will be possible to score the speaking performance of the participants easily and to use these speaking scores to compute the relationship between proficiency and the whole speaking performance, instead of just computing the effect of proficiency on the number of errors learners made.

Future researchers can assess the idea that paralinguistic features and non-verbal communication elements may be investigated in connection with pragmatic issues. Different groups with different L1 backgrounds may be examined with regard to their use of paralinguistic and non-verbal communication features to reveal whether they have any similarities or differences in use of these features.

\section{CONCLUSION}

The present study has been carried out to investigate the errors in spoken English data arisen from L1 interference by Turkish EFL learners. To clarify whether proficiency level has any effect on the total number of errors is the second objective of the study. After collecting data from 30 participants and forming two different English proficiency level groups talking about 
two different topics, the L1-based interlingual errors have been first identified and then classified into three main groups with several subtypes. Accordingly, prepositional interference is the most frequent error type by the two different proficiency groups, lexical interference ranks second and grammatical interference, third. Furthermore, the errors made by the two groups do not differ significantly with regard to their frequency. In other words, the number of errors obtained in this sample and made by the two different proficiency levels cannot be extended to the population. The mean difference of the number of errors made by the two groups is not enough to obtain meaningful results relating to clear differences between the two different proficiency groups.

Various reasons can be listed to account for the source of errors stemmed from learners' L1. With regard to grammatical L1 interferences, the grammatical differences between Turkish and English and the absence of some English grammatical forms in Turkish can be regarded as reasons causing interference. Quantifier and noun agreement leap to the eye as a source of error, and so does a grammatical form constituted in different ways in Turkish and English. Absence of indefinite articles and pluralization of uncountable nouns in Turkish are sources of error in Turkish EFL learners' spoken interlanguage.

As for prepositional L1 interferences, head-directionality parameter comes into prominence. Turkish and English have two different syntactic orders: Turkish is a head-final and English is primarily a head-initial language. Thus, while English primarily requires prepositions, Turkish primarily needs postpositions. This difference appears as a reason causing L1 prepositional interferences in Turkish EFL learners' speech production. They make errors by adding an extra preposition and by replacing the essential item with an incorrect one.

With regard to lexical L1 interferences, thinking in the native language instead of in the foreign language is another error-provoking reason and causes Turkish EFL learners to make direct translation from Turkish into English and to use an inadequate lexical item.

\section{PEDAGOGICAL IMPLICATIONS}

The study is of importance with regard to the effect of the mother tongue on the target language. Such an analysis is also relevant insofar as it reveals underlying reasons causing errors: it sheds light not only on learners' misuses, but also on factors causing errors in learners' speaking performance. It is surely beyond doubt that the results are of interest to English teachers having the same L1 as participants because the former are provided with direct feedback on student current linguistic knowledge and because it shows the failing points of the EFL teaching process. L1-based contrastive analysis also provides benefits to 
ESL teachers with a different L1 from their students by providing them with in-depth knowledge about learners and potential errors that may arise from several different L1s.

Curriculum designers may benefit from the results of contrastive analysis studies. These studies resemble needs analysis in some way. The errors help to identify the learners' current English proficiency level in depth, and the curriculum design process takes shape according to the potential error-causing factors.

The researchers find an opportunity to get learner output and to give corrective feedback to unnatural use of standard English. These studies concentrating on learner errors not only enable the researchers to see to what extent the communicative input is internalized by learners, but also provide learners with negative evidence on their deviant use of English.

\section{NOTES}

1 In this table, the asterisk indicates incorrect usage.

\section{REFERENCES}

Abbasi, M. \& Karimnia, A. (2011). An analysis of grammatical errors among Iranian translation students: Insights from interlanguage theory. European Journal of Social Sciences, 25(4), 525536.

Alonso-Alonso, M. R. (1997). Language transfer: Interlingual errors in Spanish students of English as a foreign language. Revista Alicantina de Estudios Ingleses, 10, 7-14.

Ander, S. \& Yıldırım, Ö. (2010). Lexical errors in elementary level EFL learners' compositions. Procedia-Social and Behavioral Sciences, 2(2), 5299-5303.

Bhela, B. (1999). Native language interference in learning a second language: Exploratory case studies of native language interference with target language usage. International Education Journal, 1(1), 22-31.

Brown, H. D. (2007). Principles of Language Learning and Teaching. New York, NY: Longman.

Burt, M. K. (1975). Error analysis in the adult EFL Classroom. TESOL Quarterly, 9(1), 53-63.

Butt, M. I. \& Rasool, S. (2012). Error Analysis of the Writing of Pakistani College Students: From Causes to Types to Rectification. Kashmir Journal of Language Research, 15(1), 1-23.

Corder, S. P. (1967). The Significance of learner's errors. International Review of Applied Linguistics in Language Teaching, 4, 161-170.

Dulay, H. C. \& Burt, M. K. (1974). Errors and strategies in child second language acquisition. TESOL Quarterly, 8(2), 129-136.

Dulay, H., Burt, M. \& Krashen, S. (1982). Language Two. Oxford: Oxford University Press.

Elk1lıç, G. (2012). Mother tongue traces of Turkish university students on composition papers written in English. Procedia-Social and Behavioral Sciences, 47, 656-664.

Ellis, R. (2003). Second Language Acquisition. Oxford: Oxford University Press.

Erdoğan, V. (2005). Contribution of error analysis to foreign language teaching. Mersin University Journal of the Faculty of Education, 1(2), 261-270.

Erkaya, O. R. (2012). Vocabulary and L1 interference-Error analysis of Turkish students' English Essays. Mextesol Journal, 36(2), 1-11.

Gass, S. M. \& Selinker, L. (2008). Second Language Acquisition: An Introductory Course. New York, NY: Routledge. 
Gustilo, L. \& Magno, C. (2012). Learners' errors and their evaluation: The case of Filipino ESL writers. Philippine ESL Journal, 8, 96-112.

Jarvis, S. \& Pavlenko, A. (2008). Crosslinguistic Influence in Language and Cognition. New York, NY: Routledge.

Khansir, A. A. (2013). Error analysis and second language writing. Theory and Practice in Language Studies, 3(2), 363-370.

Kırkgöz, Y. (2010). An analysis of written errors of Turkish adult learners of English. ProcediaSocial and Behavioral Sciences, 2(2), 4352-4358.

Kroll, B. M. \& Schafer, J. C. (1978). Error-analysis and the teaching of composition. College Composition and Communication, 29(3), 242-248.

Londoño-Vásquez, D. A. (2008). Error analysis in a written composition. Profile Issues in Teachers' Professional Development, 10, 135-146.

Nezami, A. \& Najafi, M. S. (2012). Common error types of Iranian learners of English. English Language Teaching, 5(3), 160-170.

Patten, B. V. \& Benati, A. G. (2010). Key Terms in Second Language Acquisition. New York, NY: MPG Books Group.

Politzer, R. \& Ramirez, A. (1973). An error analysis of the spoken English of Mexican-American pupils in a bilingual school and a monolingual school. Language Learning, 23(1), 38-61.

Saville-Troike, M. (2006). Introducing Second Language Acquisition. New York, NY: Cambridge University Press.

Şanal, F. (2008). Error-analysis based second language teaching strategies. Selcuk University Social Sciences Institute Journal, 20, 597-601.

Ting, S. H., Mahadhir, M. \& Chang, S.L. (2010). Grammatical errors in spoken English of university students in oral communication course. GEMA Online Journal of Language Studies, 10(1), 5370 .

Watcharapunyawong, S. \& Usaha, S. (2013). Thai EFL students' writing errors in different text types: The interference of the first language. English Language Teaching, 6(1), 67-78.

Zheng, C. \& Park, T. J. (2013). An analysis of errors in English writing made by Chinese and Korean university students. Theory and Practice in Language Studies, 3(8), 1342-1351. 